\title{
HIGHER EDUCATION RANKING AND QUALITY ASSURANCE: ISSUES AND CRITICAL ASSESSMENT (GENERAL PROBLEM)
}

\author{
Muhammad Wildan Shohib ${ }^{1)}$ \\ ${ }^{1}$ Kulliyyah of Education, \\ International Islamic University Malaysia-IIUM
}

\begin{abstract}
University rankings and quality assurance have become a widespread phenomenon in an increasingly competitive world of higher education. They differ with regard to their aims, objectives, target groups, and to their relationship to quality assessment. Generally, rankings are the result of an external assessment of the performance of higher education institutions; they enable transparency about systems of higher education. This paper discusses the relationship of rankings and quality assurance on an institutional and a system level. The discussion of the issue includes pros, cons of arguments and assertions following by conclusion and recommendation. A clear conception of the differences between rankings and other forms of assessment of higher education institutions helps to understand the usefulness as well as the limitations of rankings and helps to prevent false or unrealistic expectations of rankings. The discussion also included the critical issues and assessment about the true meaning of quality assurance as well as the ranking in higher educational institution.
\end{abstract}

Keywords: Quality Assurance, University Ranking, Shanghai Jiao Tong University, Times Higher Education Supplement, Higher Educational Institution

\begin{abstract}
Abstrak
Peringkat universitas dan jaminan kualitas telah menjadi fenomena di dunia pendidikan tinggi yang semakin kompetitif. Hal tersebut dibedakan berdasarkan tujuan, sasaran, kelompok sasaran, dan hubungannya dengan penilaian kualitas. Umumnya, peringkat adalah hasil penilaian eksternal terhadap kinerja lembaga pendidikan tinggi; hal tersebut memungkinkan transparansi tentang sistem pendidikan tinggi. Tulisan ini membahas hubungan peringkat dan jaminan kualitas pada tingkat kelembagaan dan sistem. Pembahasan masalah ini meliputi pro, kontra argumen, dan pernyataan yang diikuti oleh kesimpulan dan rekomendasi. Konsepsi yang jelas tentang perbedaan antara peringkat dan bentuk penilaian lain dari lembaga pendidikan tinggi membantu untuk memahami kegunaan serta keterbatasan peringkat dan membantu untuk mencegah penghitungan peringkat yang salah atau tidak realistis. Tulisan ini juga mencakup isu-isu kritis dan penilaian tentang arti sebenarnya dari jaminan kualitas serta peringkat di institusi pendidikan tinggi.
\end{abstract}

Kata kunci: Jaminan Kualitas, Peringkat Universitas, Universitas Jiao Tong Shanghai, Tambahan Pendidikan Tinggi, Institusi Pendidikan Tinggi

\section{INTRODUCTION}

The growing demands for good quality in higher education institution by students and society imply that Higher Educational Institution (HEI's) recently face the similar pressures with the business sector for few decades. This phenomenon has often become even more serious for HEI's who lack the finance, infrastructure, human resources and have recognition issues, as well as facing stronger competition from 
local, distance and international education institutions. Basically, quality and ranking have become a prevalent phenomenon and big issues in an increasingly competitive world of higher education in $21^{\text {st }}$ century. They are different with regard to their aims, objectives, target groups, and with regard to their relationship to ranking and quality assessment. This paper discusses the link between ranking and quality assurance on higher educational institution. It is also highlight some of the issues related to the indicator of assessment and quality measurement. Moreover, the differences between ranking, quality assurance and other form of assessment in higher educational will further clearly explore here. These would help to justify the contradict understanding of the term and definition as well as the limitations of rankings and helps to prevent false or unrealistic expectations of rankings and QA.

Generally, quality assurance and ranking are an external measurement of the performance of higher education institutions; they enable transparency about systems of higher education institution. In order to evaluate performance in relation to the standards, quality assurance and ranking, an institution should investigate whether these good practices are carried out and how well this is done. A set of self-evaluation scales has been arranged to assist in this process. (Self-Evaluation Scales for Higher Education Institutions) in that document the groups carrying out the evaluations within the institution are asked whether the particular practices are followed, and to rate the quality of these practices in the institution. Their judgments of quality must be based on appropriate evidence including at least some comparisons with other institutions on important items. The development of internal systems to provide that evidence is an essential requirement for an institution's quality assurance system. Unless adequate sources of evidence are available an institution cannot be considered for accreditation.

\section{DISCUSSION}

In regard with the quality and ranking, firstly, it is clearly important to start by defining the terms and phrases of quality assurance in higher education. The term of quality assurance is defined as an educational definition is that of an ongoing process ensuring the delivery of agreed standards. These agreed standards should ensure that every educational institution where quality is assured has the potential to achieve a high quality of content and results (Crosby, 2001). Quality is often described as the totality of features and characteristics of service that bear on it is ability to satisfy the 
needs of students and society as customers. Furthermore, another definition was stated on article of the world declaration on Higher Education published in United States; it is multi dimension concept, which should hold all it components, aspects and activities including teaching and academic programs, research and scholarship, staffing, students, building, facilities, equipment, service the community and the academic environment. The measurement in quality assurance involve the form of internal self-evaluation and external review, basically it was conducted openly by independent specialists, if possible, with international expertise, which are very crucial in developing institution quality. It is required also in maintaining quality in higher educational institution to characterize it is international dimension including: interactive networking, exchange of knowledge, mobility of teachers and students, and international research projects, while taking into account the national cultural values and circumstances.

Secondly, in regard with ranking system, one of the reasons in establishing the university rankings were to generate transparency about the higher education system in a competitive system for market purposes, future students, employers and their parents. Basically, it can be said that rankings in higher educational institutions are simultaneously the outcomes and results of competition. Rankings can be understood as an urgent of the knowledge society (Sadlak and Liu, 2007, p.77). Meaning to say that they are reproducing the competitive structures they are trying to measure. University are ranked based on the several indicators including the academic research performance, alumni and staff winning Nobel prizes and field medal, high cited researches, paper publication, papers indexed per capita academic performance of institution. The higher score for institution is when it assigned with the score100. The details of indicator that should be measured generally include the quality of education, quality of faculty, research output and per-capita performance. In addition, the percentage of every indicator examined using standard statistical techniques in order to adjust the indicator in ranking. The detail definition of indicators and it is explanation will be discussed further in the next chapter.

The following chapter deals with the various intentions concerning to the purposes of quality assurance and university rankings. To begin with, basically quality assurance can have different purposes, and the two most commonly are accountability and enhancement. The main purposes of quality assurance include quality 
enhancement, guaranteeing minimum standards, information provision and the creation of trust, internationally. Actually, the main global of expectation of the higher education institution on applying the external quality assurance are as follows: First, focusing to support the enhancement of quality in higher education institution in order to achieve the recognition from local even international organization standard. Quality assurance also provides consumer protection and guarantor of acceptable or minimum standard. On the other hand, due to maintaining the quality of the institution it is important to increase trust, which would provide a better basis for recognition and trust facilities mobility. External quality assurance also may support the international collaboration through increased trust in different system.

Furthermore, QA also provides the consumer independent and reliable information on Higher Education Institution and programs and their quality. Quality Assurance is a condition that leads to the achievement of transparency. It will ensure the quality of the academic (teaching, curriculum etc) and structural (buildings, computers etc) provision of courses and it will allow an objective review of their quality. The transparency should be dialectical, meaning that the quality assurance should make institutions transparent, but also that the quality assurance in itself should be transparent, allowing the outcomes to be shared by the participants (actors).

As students we particularly want to overcome the obstacles to the effective exercise of free movement of students, recognition of courses and qualifications and guarantee the 'fitness for purpose of our education' and ensure that the outcomes of higher education meet student's expectations. As the result of QA assessment, the institutional ranking should be measured. The choice of methods used to prepare rankings should be clear and unambiguous. This transparency should include the calculation of indicators as well as the origin of data. The choice of data should be grounded in recognition of the ability of each measure to represent quality and academic and institutional strengths, and not availability of data.

In addition, rankings should measure outcomes in preference to inputs whenever possible. Measures of outcomes provide a more accurate assessment of the standing and/or quality of a given institution or program. And finally, rankings should apply measures of quality assurance to ranking processes themselves. These processes should take note of the expertise that is being applied to evaluate institutions and use 
this knowledge to evaluate the ranking itself. Rankings should be learning systems that continuously apply this expertise to develop methodology.

Moreover, as a result of external quality assurance, the purpose ranking is referring to three key issues in the approximation to the university ranking systems: who ranks, why rank and the audience for rankings. Most of the university rankings have been done by private and media-based entities (e.g., magazines). However, professional associations and governments are paying more and more attention to this option. Regarding the question about why does the university is rank? Basically, the main purpose is to give information to the consumers in order to help them to make higher education choices. Other important purpose is to function as an institutional marketing strategy.

A last purpose refers to the promotion of quality of education institutions motivating competence among them. Furthermore, the third key issue is the audience for rankings. Students are considered the more important consumers and parents are other key collective since they pay expending of students' education. Other consumers are the academic entities and government institutions responsible of education politics. Rankings can provide comparative information and improved understanding of higher education, but should not be the main method for assessing what higher education is and does; rather, they can complement the work of government, accrediting authorities, and independent review agencies. Moreover, Rankings must recognize the diversity of institutions and take the different missions and goals of institutions into account. Quality measures for research-oriented institutions, for example, are quite different from those that are appropriate for institutions that provide broad access to underserved communities.

In this section, the instrument of quality assurance and university ranking will be further clearly highlighted as well as the general aspects of the relation between both factors. To begin with, the topic of quality assurance originally came from business and company sector but now it is expanding in education institution and public service sector. Especially in educational sector the word quality is not narrow to the institutional performance it is also include how far the institution recognized by other organizations locally and internationally.

Quality assurance and university ranking are remaining at the most essential attribute that may create values and standards about the outcome and products that 
might differentiate between their competitors in higher educational institution. Furthermore, the higher educational institution should learn from the business center in maintaining high quality of product/services and how these can be transferred to higher educational institution. The adaptation of the strategies that have been used in business sector in improving their standard and quality would help the educational institution in creating high standard and quality in education. When the higher educational institution could advance it is standard and quality means that they are also might to ease of the problems such as falling students' number, funding, recognition, and qualification.

Analytically, the existing instruments of quality assurance can be well described along this chapter and different approaches to quality assurance will be further discussed. There are three main approaches to quality assurance namely as accreditation, assessment and audit. The accreditation and evaluation include assessment and audit focus on maintaining the quality teaching and learning. Whereas the audit more focus on internal procedures in order to achieve the objectives. Firstly, accreditation is an internal evaluation made whether an educational institution or program have met a threshold standard and qualifies for a certain status.

Obtaining accreditation may have implications for the Higher Education Institution itself. The focus of accreditation is comprehensive, examining the mission, resources, and procedures of a Higher Education Institution or program (Dill, 2000). The output of an accreditation is a yes/no decision, though graduations are also possible (Woodhouse, 1999). Secondly, assessment is an evaluation that makes graded judgments about quality, in this respect it goes beyond accreditation that makes a binary judgment (Dill, 2000).

Assessment asks "how good are your outputs?" The output of an assessment is a quantitative evaluation, a grade whether numeric, literal or descriptive. The third is audit; a quality audit checks the extent to which the institution is achieving its own explicit or implicit objectives (Woodhouse, 1999. Furthermore, intern of level that should be reviewed. The subject still on the debate whether the quality assurance focus on the instructional level or instead on academic program. Practices vary widely among Western European countries.

In Denmark, the Netherlands and Portugal the focus is on academic programs, in some HEIs in Germany the reviews focus on the institutional level, while in France, 
the United Kingdom and Ireland both institutional and program reviews are carried out. Outside of Europe, many countries have begun with institutional reviews but, as their systems experienced growth in professional fields of study, there has been a trend towards program-wide approaches (El-Khawas et al., 1998).

Moreover, "For each academic program it is possible to define standards, or minimum requirements to be expected from the graduates. Standards can be described as a statement in general or specific terms of the knowledge, understanding, skills and attitude to be demonstrated by successful graduate. The evaluation criteria can be formulated by a quality assurance agency, a government body, an expert group or a professional organization, but they are also often formulated jointly by diverse stakeholders. For instance, in the US standards for recognition of accrediting organizations are defined by the recognizing institutions (CHEA - independent institution and USDE - federal agency).

In Australia, the National Protocols for Higher Education Approval Processes were recommended by the Joint Committee on Higher Education (composed of representatives from the Commonwealth and each State and Territory department with responsibility for higher education) and approved by the Ministerial Council on Education, Employment, Training and Youth Affairs (AQF, 2000). In Japan, requirements for establishing a new institution are stipulated in a ministerial ordinance, the "Standards for University Establishment" (Kimura et al., 2004).

Most of quality assurance agencies use three basic methods for it is quality review. Namely self-review and then followed by peer review and external review. First is self-review, it is a key element in most evaluation procedures. It provides a standard against which the Higher Education Institution can measure itself and a framework for building up a definition of quality. Thus, it helps the Higher Educational Institution check how far it is achieving its strategic mission and goals, and it allows it to prepare an action plan for further development.

Self-reviews are carried out by many Higher Educational Institution though their nature varies significantly (Brennan and Shah, 2000). In the US, there has been a long tradition of conducting self-reviews (generally termed self-study) in accreditation procedures and HEIs tend to have a strong capacity for the collection, analysis and interpretation of information for such procedures (Brennan, 1997). In Europe, a selfreview is included in $94 \%$ of the assessment and $68 \%$ of the accreditation procedures. 
Second one is peer-review, it is an evaluation carried out by another academic or academics, usually in the same discipline. Peer-reviews, already dominant in research evaluation, are increasingly used in the evaluation of teaching and learning as well.

However, who is considered as a peer varies in different quality assurance systems (Brennan and Shah, 2000). In US accreditation procedures peer-reviews involve faculty and administrative peers in the profession and are carried out for reviewing the self-study and for conducting site visits (Eaton, 2004). And the last is external review that is quality review panels include non-academic members and people from other countries in addition to peers. In the US for instance, the review panel may also include non-academic public members who have an interest in higher education. In the Danish quality assurance system there are permanent, salaried external examiners and the review panel includes not only professional or academic experts, but also representatives of employers (Thune, 1998).

Now, we are moving to the instrument of university ranking and International recognition in higher educational institution. In this section some of the general aspects of the relation between ranking and quality will be discussed clearly. These are with correlated with regard to the both national and international rakings. Basically, the two-international ranking for higher educational institution was introduced among world classes University namely Shanghai Jiao tong University and the world rankings compiled by the Times Higher Educational Supplement.

The two institutions in the recent two decades have recognized higher educational ranking in many countries all over the world. Despite their now long tradition (the first ranking by US News \& World Report was published in 1983), rankings are still very controversial and they are being widely criticized, have drawn attention throughout the world in particular within higher education institutions competition.

Rankings were established to create transparency about the higher education system in a competitive system for market actors, prospective students, their parents, employers. Both rankings follow a similar approach despite applying different indicators. Primarily, both are rankings of whole institutions; although they now offer some additional differentiation by fields and both follow the league table approach.

Both rankings have a clear focus on research, even stronger in the Shanghai ranking. In the calculation of the overall score, the THES ranking relies heavily on 
reputation (among academics and employers), which counts for fifty percent of the total score (Federkeil, 2008). The THES, in addition, offers some indicators of the internationalization of institutions with regard to students and staff and with a weight of twenty percent of student and staff ratios.

The Shanghai ranking exclusively refers to research (Liu and Cheng, 2005). Sixty percent of the total score depends on publications and citations, thirty percent on Nobel Prize and Field Medal (mathematics) winners. Hence, implicitly this ranking suggests that 'world class' quality derives from research, whereas in the THES ranking quality is largely identified by reputation. This ranking is the result of a detailed study of more than 2000 world universities, although only the top 500 universities are published. Indicators fundamentally based on scientific research are the following:

a. Total number of the alumni of an institution winning Nobel Prizes and Fields Medals (10 per cent of the total).

b. Total number of the staff of an institution winning Nobel Prizes and Fields Medals (20 per cent of the total).

c. Number of highly cited researchers in 21 broad subject categories (20 per cent of the total).

d. Number of articles published in Nature and Science between 2000 and 2004 (20 per cent of the total) (for institutions specialized in humanities and social sciences this indicator is not considered, and its weight is relocated to other indicators).

e. Number of articles cited in Science Citation Index-expanded (SCIE), Social Science Citation Index (SSCI) and Arts \& Humanities Citation Index in 2004 (20 per cent of the total).

f. Size of institution: Total scores of the above five indicators divided by the number of full-time equivalent academic staff (10 per cent of the total). For each indicator, the highest scoring institution is assigned a score of 100 , and other institutions are calculated as a percentage of the top score. Standard statistical techniques are used to adjust the indicators if necessary. Scores for each indicator are weighted according to percentages above indicated to arrive at a final overall score for each institution. The highest scoring institution is assigned a score of 100, and other institutions are calculated as a percentage of the top score.

This chapter is going to highlight the problem and debates in regard with indicators of university ranking and quality assurance. Both Shanghai Jiao Tong 
University and Times Higher Education Supplement rankings have been subject to several debates and severe critics. Basically, some of those critics apply in the same way to both rankings while others are specific to a given ranking. Most studies agree that it is preferable to use objective indicators of research outputs rather than subjective measures such as peers' opinion.

First of all, in regard with The Shanghai Jiao Tong University ranking, basically, the most of the critics against the SJTU ranking are twofold. Firstly, and the most important point, only the research dimension of universities is taken into account. The SJTU team justifies the use of research-oriented indicators by the impossibility to compare teaching quality between universities at an international level. However, a general interpretation is often given to the SJTU ranking, although the relationship between research performance and teaching quality is far from being well established.

In addition, given that a great number of students who take up university studies may not necessarily follow an academic career or undertake a research-based job, the ranking is of little use to them. The SJTU ranking thus overlooks at the numerous other social and private benefits associated with university education. Moreover, even if one agrees on the use of research-based indicators, it is questionable whether it is appropriate to consider as adequate measures of current research some rare and potentially lagged achievements such as Nobel prizes, which are, in addition, only awarded in a limited number of fields.

Finally, although the SJTU indicators express objective measures of research quality, they strongly downplay social sciences and humanities. Second, five out of six indicators (which represent $90 \%$ of the total weight) are size dependent indicators. This strongly favors ceteris paribus large institutions and does not give information on the real productivity of the staff of the institution. In 2007 for example, the University of Basel ranks $82^{\text {nd }}$ in the overall rating and 27 th with the academic performance indicator. On the contrary, the Johns Hopkins University is in the top 20 of the lists but drops by more than 60 positions when the academic performance indicator is used instead. This simple example shows that the choice of size-dependent versus size adjusted indicators makes, for some institutions, an enormous difference in the final result. In response to this critic, league table compilers are thinking to increase the weight of the last indicator in the next editions of the ranking. 
The second is about The Times Higher Education Supplement ranking, there are big number of authors are concerned with the use expert-based indicator which are (50\% of total weight) due to the possibly ambiguous conclusions on the final university rating stemming from the continuous changes in methodology over the four editions of the THES ranking. Regarding the use of expert driven indicators on university performance measurement and the lack of transparency close to the process of selection and experts involved in the review process transmit serious doubts about the reliability of the overall THES ranking. Not being transparent enough regarding the methodology is subject to criticisms. However, it might also be an aware or unconscious way of avoiding detailed comments that would cause to be less credible the final ranking. Moreover, beside peer review indicators measure the reputation of a university rather than the "contemporaneous" research performance. This is based on the result of statistical part that has been reported. Either of the two expert-based indicators and the indicator on citations low degrees of correlation that are in most cases not statistically different from zero.

In addition, in regard with the indicator on citation that based on the 10 years of citation, it is indicated that Scopus has replaced Thomson Scientific as data supplier for citations in the fourth edition. Finally, while in the first three editions, each institution's score was calculated as a percentage of the best performing one, the indicators in 2007 were first standardized before being converted into a score between 0 and 100. Even if the THES team argues that those changes were necessary in order to improve the quality of the ranking, it is very difficult to disentangle time variations in the performance of universities from changes that are the result of a statistical artifact. For example, the Adelaide University rises in the overall ranking by 40 positions between 2006 and 2007. Is this shift the consequence of an improvement in the university's performance or is it the result of the statistical changes implemented in the 2007 THES ranking?

\section{General Comments Pro and cons}

In addition, the both rankings are relying highly on bibliometric indicators. As commented by Zitt and Filliatreau (2006) and Van Raan (2007), bibliometric based indicators tend to be biased towards English speaking and hard sciences intensive institutions. Indeed, non-English journals are often not included in the Citation Indices and articles published in non-English journals are less cited on average than those 
published in English. In addition, journal coverage by SCOPUS or Thomson ISI is still not satisfactory for social and human sciences. In average, SCOPUS covers a larger number of papers and journals than the Thomson ISI Database. In addition, more sources in languages other than English and in humanities and social sciences are included in the SCOPUS database than in the first one. Publications in refereed journals are also far from being the only publication practice in soft sciences. Finally, citation habits of different scientific disciplines vary a lot between disciplines with a bias in favor of hard sciences.

Furthermore, the methods used to compile league tables are not always justifiable. Important aspects of institutional performance have proved impossible to capture with adequate statistical robustness. Data require interpretation and some conceptual framework, but league tables often combine performance indicators in an ad hoc way that may not even reflect the compilers' own concept of quality or excellent performance as stated in their publicity materials. The indicators selected and weightings applied are often not supported by an explicit rationale. The methodologies used to compile league tables might lead to misleading conclusions. Indeed, the difference in scores between institutions placed several positions apart may not be statistically significant, even though the difference in positions suggests a disparity in quality or performance. Alterations in methodology from year to year in the data sources, indicators, procedures for calculating scores, weightings, ranking methods, etc produce fluctuations in institutional positions that have nothing to do with changes in quality or performance but maybe the result of the facts table is not immune from cultural bias.

Moreover, this section discussed the pros and cons and difficulties regarding the implementation of effective quality assurance system. It has been identified that different interests may create conflict between government and universities in their approach to quality assurance. Government has more a summative approach, while the approach of the universities tends to be more formatives. On the other hand, based on Vroeijenstijn (1995) argues that governments and Higher Educational Institution are in most countries still opponents on the 'why' of external quality assurance. However, government is interested both in accountability and improvement. It aims at demonstrating to the society it makes justifiable decision on educational policy (such as allocation of funding or termination of academic programs). Furthermore, the 
universities' main objective is quality improvement. Their concerns are whether it is possible to offer high quality education within the conditions set by the government and to convince the public that the quality of their educational provision is the best possible.

For Higher Educational Institution, the most important function of quality assurance is an analysis of strengths and weaknesses and the formulation of recommendations for further improvement. However, Higher Educational Institution also emphasizes the accountability function of QA. Particularly, it's related to the role of process of self-regulation, internal steering and quality assurance. This difference in the conception of quality can make the successful implementation of quality assurance systems more difficult. Watty (2003), referring to several case studies, suggests that academics adopt a variety of behaviors when quality led initiatives are implemented. It is argued that there seems to be little evidence that the majority of academics are embracing quality change initiatives. One explanation may be that conceptions of quality can differ between academics and other stakeholders in higher education, which generates a potential for conflict.

Arguments supporting and opposing the use of performance indicators in quality assurance are discussed in this section. First, the arguments supporting the use of QA see the performance indicators allow an objective measurement and comparability of quality, which are important to government. Performance indicators are regarded as useful tools both for accountability purposes and in informing policy and decision making. They aim at discharging established accountability obligations to the public and elected officials by providing a relatively straightforward set of publicly available statistics about 'performance'. For governments, a major role of indicator of Quality Assurance is to collect objective information on the performance of HEIs and to provide them with objective measurement of the quality.

Moreover, the argument that opposing the use of indicator of QA seen the performance indicators are reductionist and there is a risk of manipulation of data by Higher Educational Institution. Reportedly, many academics have been opposed to the increasing use of performance indicators, arguing that they are reductionist, offer inaccurate comparisons, and are unduly burdensome (El-Khawas et al., 1998). Middlehurst and Woodhouse (1995) also warn against the pitfalls in comparisons. It is argued that popular discussion often trivializes comparisons, selecting only one or two 
aspects, reducing them to simplistic terms and paying little regard to whether the aspects are truly commensurate. Furthermore, the use of performance indicators might encourage manipulation of data by HEIs to meet targets (Harvey, 2002). Knight (2001) also points out that summative assessment data of student performance are unreliable and routinely mis manipulated.

Secondly, the link between performance indicators and quality is not evident. Another criticism concerning performance indicators is that there is no necessary link between performance indicators and quality. Quality is about much more than output measures, it is also about inputs, including the quality of the teaching staff, and the quality of the equipment and laboratories available within Higher Educational Institution (Thune, 1998). Moreover, a major problem highlighted by several authors is the difficulty in measuring the quality of both research and teaching. For example, is the total number of publications a true measure of quality in research? Or is a high success rate in education a sign of quality, or does it reflect the reduction of standards? (Vroeijenstijn, 1995a) However, measuring and comparing research performance still seems to be less problematical than that of teaching and learning. Baldwin (1997) in a study on Australian quality assurance mechanisms suggests that most academics seem to accept the fact that peer judgments of quality are built into processes of refereeing publications and applications for research grants.

To sum up, among the different instruments of quality assessment in higher education, rankings probably get the most public attention. Rankings are a growing phenomenon in higher education and are published in many countries throughout the world. Despite their controversial nature, they are here to stay, as they correspond to a need for transparency about higher education in an increasingly competitive system. Basically, the main purpose of ranking is to create transparency about higher educational institution from an external and comparative perspective.

Institutional improvement is at best a secondary aspect of rankings and quality assurance. However, the result of ranking is taken seriously by institution ranked in order to measure the university performance based on the indicator classification. Moreover, through quality assessment and ranking the educational institution seek to cope with the weaknesses that have been identified by the ranking. It is only the sense that sometimes ranking and quality assessment can contribute to the institutional 
quality assurance. That should be used as a starting point for educational institution to analyze the strength and weakness when it is compared to their competitors.

An analysis of existing rankings and quality assessment show that the huge majority of rankings do not have an explicit and theoretically grounded concept of quality. They develop a specific set of indicators according to their aims and target groups. And they are often, simply with regard to the availability of data. Moreover, their set of indicators constructs an implicit model of quality or excellence of higher education institutions. Nevertheless, in most rankings' quality is largely constructed by measures of input. In particular, in an international context only a few valid, reliable, and really comparable indicators of outputs exist. They are restricted to the measurement of research activities in the field of the natural sciences. However, there is still no a valid concept for an international or even world-wide ranking of research activities in other academic fields than sciences nor a well-developed concept for a worldwide ranking of teaching and learning.

In conclusion, to be useful of internal quality assurance as described above statement, the rankings must fulfill several criteria in order to achieve the real meaning of quality. It is suggested that, first ranking must find a balance in their set of indicators and the way that they are present their results between their aims to inform external target group about higher education and identify the need of higher educational institution to elaborate and thorough insights in their performance. Secondly, according to the range of data should be broaden enough in order to allow an analysis of different aspects performance that assessed.

Third, the data should refer to the single scientific field aspect, or disciplines and programs to ease for putting the result. Moreover, the analysis for internal quality assurance needs to be disaggregated on the different unit within educational institution. This aims to see the data that should be disaggregated into fields, then the institution can see which fields are good and which are needed to be improved in order to develop measures and incentives for improvement.

Fourth, data should not give an impression of carefulness that is not inherent in the data. In particular, there is a danger of misinterpreting differences in rank positions in terms of difference in quality or performance if the differences in the numerical values of the indicators are very small. Last but not least, as an alternative to constructing league tables the Central Higher Education rank orders universities in 
three groups: the best universities are clustered into the top group, the worst into the bottom group, and the rest constitute an intermediate middle group including Islamic university as exception.

The grouping procedure varies according to two kinds of indicators: factual data (for example, staff, student ratios, number of publications) are grouped according to quartiles. The upper quartile and the lowest quartile are ranked respectively the top and the bottom, and the middle two quartiles are ranked intermediate. In the case of subjective indicators based on survey data, i.e. judgments by students and professors, the procedure takes into account the diversity of judgments within universities compared to the overall score.

A university is ranked into the top group if the confidence interval of the mean (we use a scale from one, 'very good', to six, 'very bad', corresponding to German school marks) is completely below the overall mean of all universities (in a particular subject). At the other extreme, a university is ranked into the bottom group if its confidence interval is completely above the overall mean. Accordingly, a university is ranked into the middle group either if the mean is intermediate or if judgments are controversial, i.e. dispersion is high so that the confidence interval is large and hence neither completely below nor completely above the overall mean.

\section{CONCLUSION}

It suggested for an Islamic university to be assessed in different indicator and system, because they are different in the context with the western university. Islamic university has it is requirements and so many issues will arise, such as implementing Islamic and integrated curriculum. The ranking should be based on some additional criteria that absent from THES or shanghai ranking but relevant to Islamic tradition, values such as Islamicist and integrity. It is important to highlight that the true meaning of quality based on Islamic university criteria is not just limited to the measurable data and indicator of assessment. It is more to the quality of educational itself that provide with meaningful education to serve the Ummah and produce good scholars and student with better character and thinking. 


\section{REFERENCES}

Baldwin, G. (1997) An Australian Approach to Quality in Higher Education, The Case of Monash University, in Brennan, J. de Vries, P. and Williams, R. (eds.) Standards and Quality in Higher Education, Higher Education Policy Series 37, Jessica Kingsley.

Brown, R. (2000) Accountability in higher education: have we reached the end of the road? The case for a higher education audit commission, speech at University of Surrey Roehampton, 24 October.

Brown, R. Quality Assurance in Higher Education. The UK Experience since 1992. London: Routledge Falmer, 2004.

Campbell, C. and Rozsnyai C. (2002) Quality Assurance and the Development of Course Programmes, UNESCO CEPES, Papers on Higher Education.

CLARKE, M. "The Impact of Higher Education Rankings on Student Access, Choice, and Opportunity", in, Institute for Higher Education Policy, ed. College and University Ranking Systems: Global Perspectives and American Challenges. Washington. 2007, pp. 35-48.

DILL, D. and SO0, M. "Academic Quality, League Tables, and Public Policy: A Cross National Analysis of University Ranking Systems", Higher Education 49 (2005): 495-533.

EUROPEAN NETWORK FOR QUALITY ASSURANCE (ENQA). “Quality Procedures in European Higher Education”, ENQA Occasional Papers 5, Helsinki, 2003.

Finch, J. (1997) Power, Legitimacy and Academic Standards, in Brennan, J. de Vries, P. and Williams, R. (Eds.) Standards and Quality in Higher Education, Higher Education Policy Series, Vol. 37, Jessica Kingsley.

Hashim, Rosnani (2014), Critical issues and educational reform. IIUM press.

INSTITUTE OF HIGHER EDUCATION, SHANGHAI JIAO TONG UNIVERSITY, Academic Ranking of World Universities (2005) Retrieved on 1 June 2005 from http://ed.sjtu.edu.cn/ranking.htm

LIU, N.C. and CHENG, Y. "The Academic Ranking of World Universities", Higher Education in Europe 30 (2) (2005): 127-136.

Marginson, S., 2007, Global University Rankings: Implications in general and for Australia . Journal of Higher Education Policy and Management 29(2):131-142

SADLAK, J., and LIU, N.C. eds. The World-Class University and Ranking: Aiming Beyond Status. Bucharest, Shanghai, Cluj-Napoca: UNESCO-CEPES, Shanghai Jiao Tong University, Cluj University Press, 2007. 
Saisana, M., Saltelli, A., Tarantola, S., 2005, Uncertainty and sensitivity analysis techniques as tools for the analysis and validation of composite indicators, Journal of the Royal Statistical Society A 168(2):307-323.

Taylor, P., Braddock, R., 2007, International University Ranking systems and the Idea of University Excellence, Journal of Higher Education Policy and Management 29(3):245-260.

THE TIMES HIGHER EDUCATION SUPPLEMENT, The Times Higher World University Rankings 2005 (2005) Retrieved on 21 November 2005 from http://www.thes.co.uk/worldrankings/

USHER, A., SAVINO, M. "A Global Survey of Rankings and League Tables”, in, Institute for Higher Education Policy, ed. College and University Ranking Systems: Global Perspectives and American Challenges. Washington. 2007, pp. 23-34.

Usher, A., Savino, M., 2007, A Global Survey of University Ranking and League Tables. Higher Education in Europe, 32(1):5-15.

Williams, R., 2007, Broadening the Criteria: Lessons from the Australian Rankings. In Sadlak, J., Liu Nian Cai, eds. The World-Class University and Ranking: Aiming Beyond Status. UNESCO-CEPES, Shanghai Jiao Tong University, Cluj University Press

WORLD UNIVERSITIES' RANKING ON THE WEB (2005) Retrieved on 1 June 2005 from http://www.webometrics.info/methodology es.html

Zitt, M., and Filliatreau, G., 2007, Big Is (Made) Beautiful - Some comments about Shanghai-Ranking of World-Class Universities. In Sadlak, J., Liu Nian Cai, eds. The WorldClass University and Ranking: Aiming Beyond Status. UNESCOCEPES, Shanghai Jiao Tong University. 